\title{
Effects of Pig Slurry as Basal and Panicle Fertilizer on Trace Element Content and Grain Quality in Direct-Seeding Rice
}

\author{
Lifen Huang ${ }^{1, *}$, Jie Yang ${ }^{1}$, Wei Gao ${ }^{2}$, Weikang Yang ${ }^{1}$, Xiaoyi Cui ${ }^{1}$ and Hengyang Zhuang ${ }^{1, *}$ \\ 1 Jiangsu Key Laboratory of Crop Genetics and Physiology/Co-Innovation Center for Modern Production \\ Technology of Grain Crops, Yangzhou University, Yangzhou 225009, Jiangsu, China; \\ 18852713575@163.com (J.Y.); yangweikang0123@163.com (W.Y.); cuixiaoyi1996@126.com (X.C.) \\ 2 Taicang Agro-Tech Extension Center, Taicang 215400, Jiangsu, China; gaow625@sina.com \\ * Correspondence: lfhuang@yzu.edu.cn (L.H.); zhy7979356@sina.com (H.Z.); Tel.: +86-514-8797-9356 (L.H.)
}

Academic Editor: Iain Gordon

Received: 2 May 2016; Accepted: 18 July 2016; Published: 26 July 2016

\begin{abstract}
Direct-seeding rice has grown in popularity in recent years and is widespread in China. This study focused on the effects of pig slurry (PS) on grain quality and safety in direct-seeding rice. Application of more than $210 \mathrm{~m}^{3} \cdot \mathrm{hm}^{-2}$ increased rice yield and dry matter accumulation, compared with conventional chemical fertilizer treatment (CK2). At the heading and maturing stage, a high dosage of PS (T6, T8 and T9 treatments) promoted uptake of $\mathrm{Pb}, \mathrm{Cu}, \mathrm{Zn}, \mathrm{Fe}$ and $\mathrm{Mn}$ by rice plants and grain, but retarded uptake of $\mathrm{Cr}, \mathrm{Co}$ and $\mathrm{Ni}$, indicating an ability to alleviate toxicity of some heavy metals. Compared with CK2, PS alleviated the transfer of $\mathrm{Pb}, \mathrm{Cr}, \mathrm{Co}, \mathrm{Ni}$ and $\mathrm{Cu}$ from straw to grain, but enhanced the transport of Zn, Fe and Mn. Although PS application slightly diminished the processing quality, including brown rice, milled rice and head milled rice, it significantly decreased the amylose content, optimized the starch profile, and improved the overall quality. The results confirmed the feasibility and safety of PS application to direct-seeding rice, and determined that PS basal and panicle fertilizer could increase yield and improve the rice quality when applied between 210 and $240 \mathrm{~m}^{3} \cdot \mathrm{hm}^{-2}$.
\end{abstract}

Keywords: pig slurry; trace elements; direct-seeding rice; rice quality

\section{Introduction}

As a traditional agricultural country, China is one of the largest producers of animal manure in the world, with an annual output of more than 3 billion tonnes [1]. Disposal of animal manure usually involves aerobic composting and anaerobic fermentation [2]. Pig slurry (PS) is primarily used as fertilizer in agricultural production to provide nutrients such as nitrogen $(\mathrm{N})$, phosphorus $(\mathrm{P})$, and potassium (K) to crops [3-6]. Tao et al. [7] found that applying PS at $60-120 \mathrm{~m}^{3} \cdot \mathrm{hm}^{-2}$ instead of chemical fertilizer at $30-60 \mathrm{~kg} \mathrm{~N} \cdot \mathrm{hm}^{-2}$ during winter, at the panicle formation stage, could meet the high nitrogen demand utilization efficiency of wheat. Moreover, Gomez-Munoz et al. [8] demonstrated that acidification of PS increased $\mathrm{N}$ availability from separated solid fractions but did not affect $\mathrm{N}_{2} \mathrm{O}$ and $\mathrm{CO}_{2}$ emissions.

However, continual application of high doses of PS can result in high concentrations of heavy metals, especially copper $(\mathrm{Cu})$ and Zinc $(\mathrm{Zn})$, which could lead to secondary contamination in a PS-amended soil $[9,10]$. Concentrations of $\mathrm{Cu}$ and $\mathrm{Cd}$ in grain and straw were dependent on the available $\mathrm{Cu}$ and $\mathrm{Cd}$ in the soils, and soil available $\mathrm{Cu}$ and $\mathrm{Cd}$ were significantly affected by the soil $\mathrm{pH}$ [11]. Heavy metals in variable charge soil are highly bioavailable and easy to transfer into plants. The use of organic fertilizer such as biogas slurry in As-contaminated paddy soil can significantly alter 
the behaviour of As in a soil-rice system and enhance As accumulation in rice plants [12]. The As concentrations in polished grain were reported to be positively and significantly correlated with As root-grain translocation factor [13]. The $\mathrm{Cu}$ content in stems and leaves in anaerobically digested PS was reported be significantly higher $(p<0.05)$ than that in a chemical fertilizer treatment [14]. Although there is a potential risk of heavy metal pollution from PS, phytotoxicity caused by $\mathrm{Cu}$ and Zn did not occur, even after several years of PS application, because chemical species in soil tend to form complexes with dissolved organic carbon, and $\mathrm{Cu}$ and $\mathrm{Zn}$ in their free forms are only present at low levels [15]. Engineered cultivars and low-accumulating genotypes could mitigate $\mathrm{CH}_{4}$ emissions and reduce heavy metal accumulation in rice grown in pig biogas-fertilized fields [16,17]. It is essential to manage and utilize PS effectively in crop production, because it is not only a useful organic fertilizer, but also a potential risk to the environment.

Direct-seeding and transplanting are the most important rice cultivation methods [18]. Rice cultivation in Asia is undergoing significant changes in response to economic factors and technological innovation in farming practices. One such change has been a shift from transplanting to direct-seeding methods for rice establishment. Compared with transplanting, direct-seeding has both advantages and disadvantages. Advantages include water- and labour-saving, higher economic returns, a shorter crop cultivation period, higher abundance and diversity in paddy fields, and lower $\mathrm{CH}_{4}$ emissions [18-21]. In China, $83.2 \%$ of rice was grown by direct-seeding in Shanghai, as was 33.3\% in Jiangsu province, and $39.7 \%$ in Zhejiang province in 2008 [22]. Direct-seeding is now spreading rapidly to farms around the middle and lower reaches of the Yangtze River. Some of the challenges of the direct-seeding method include weed management, yield loss, and poor and erratic emergence [23,24]. In contrast, transplanting produces taller plants, a greater number of grains per panicle, and a higher 1000-grain weight, and tiller number, fertile tillers, kernel and straw yield, and the harvest index is also higher than in direct-seeding $[25,26]$.

Our group previously tested PS in the production of rice and wheat, and found it can reduce the use of chemical fertilizer and protect the environment [7,27-29]. In transplanting rice, PS from pig farming can replace $70 \%$ of the chemical fertilizer used, while increasing crop yield and enhancing the content of beneficial elements, as well as altering the levels of heavy metals such as $\mathrm{Hg}, \mathrm{Cd}$ and Cr $[28,29]$. To our knowledge, application of PS to direct-seeding rice has not been reported. We predict that PS may act as a chemical fertilizer to improve yield if applied at the appropriate times and spread in the appropriate way. However, whether PS can be applied safely without inducing the accumulation of heavy metals in grains remains unknown, as do the potential effects on rice quality.

In this study, we tested various doses of PS as a basal and panicle fertilizer for growing direct-seeding rice, and measured the effect on rice yield, dry matter accumulation, and trace element uptake in straw and grain at different growth stages. Rice edibility and the rapid visco analyser (RVA) profile were also studied, as was processing quality. These results provide insight into the suitability of PS application for direct-seeding rice production.

\section{Materials and Methods}

\subsection{Study Site}

This study was conducted at the Shanghai farm in Dafeng County, Jiangsu province $\left(33^{\circ} 21.736^{\prime} \mathrm{N}\right.$, $120^{\circ} 32.012^{\prime} \mathrm{E}$ ) in 2014 . This area has a subtropical seasonal climate and a rice-wheat crop rotation system, with an annual mean precipitation of $1040 \mathrm{~mm}$, an annual mean temperature of $14{ }^{\circ} \mathrm{C}$, a frost-free period of 213 days, and annual sunshine totalling $2255 \mathrm{~h}$. The previous crop was wheat. The soil is sandy loam with $19.32 \mathrm{~g} \cdot \mathrm{kg}^{-1}$ organic matter, $1.00 \mathrm{~g} \cdot \mathrm{kg}^{-1}$ total nitrogen, $75.21 \mathrm{mg} \cdot \mathrm{kg}^{-1}$ alkali hydrolysable $\mathrm{N}$, $23.48 \mathrm{mg} \cdot \mathrm{kg}^{-1}$ Olsen-P, $216.78 \mathrm{mg} \cdot \mathrm{kg}^{-1}$ exchangeable $\mathrm{K}, 11.35 \mathrm{mg} \cdot \mathrm{g}^{-1} \mathrm{Ca}, 8.52 \mathrm{mg} \cdot \mathrm{g}^{-1} \mathrm{Mg}$, $0.71 \mathrm{mg} \cdot \mathrm{g}^{-1} \mathrm{Na}, 23.53 \mathrm{mg} \cdot \mathrm{g}^{-1} \mathrm{Fe}, 0.10 \mathrm{mg} \cdot \mathrm{g}^{-1} \mathrm{Cd}, 2.84 \mathrm{mg} \cdot \mathrm{kg}^{-1} \mathrm{Cu}, 1.00 \mathrm{mg} \cdot \mathrm{kg}^{-1} \mathrm{~Pb}, 6.71 \mathrm{mg} \cdot \mathrm{kg}^{-1} \mathrm{Zn}$, $18.81 \mathrm{mg} \cdot \mathrm{kg}^{-1} \mathrm{As}, 22.23 \mathrm{mg} \cdot \mathrm{kg}^{-1} \mathrm{Cr}$, and $0.17 \mathrm{mg} \cdot \mathrm{kg}^{-1} \mathrm{Hg}$. 
Topsoil $(0-20 \mathrm{~cm})$ samples were collected and air-dried, ground into powder and passed through a $2 \mathrm{~mm}$ sieve. Only soil $<2 \mathrm{~mm}$ was used for analyses. Total organic matter in soil was determined by mass loss upon ignition of oven-dried soil in a muffle furnace at $550{ }^{\circ} \mathrm{C}$ for at least $6 \mathrm{~h}$. Total $\mathrm{N}$ content was determined by micro Kjeldahl digestion. Alkali hydrolysable $\mathrm{N}$ was determined by the alkali solution diffusion method. Olsen-P was extracted by $\mathrm{NaHCO}_{3}$ and determined by the classic colorimetric method. Exchangeable $\mathrm{K}$ was extracted by ammonium acetate and determined by the flame photometric method. To extract the metal elements in soil, a $0.3 \mathrm{~g}$ soil sample was digested by a mixture of concentrated hydrochloric acid and nitric acid (3:1, $v / v)$ using a CEM closed microwave system [30]. The concentrations of metal elements in the extract, namely, $\mathrm{Ca}, \mathrm{Mg}, \mathrm{Na}, \mathrm{Fe}, \mathrm{Cd}, \mathrm{Cu}, \mathrm{Pb}$, $\mathrm{Zn}, \mathrm{As}, \mathrm{Cr}$ and $\mathrm{Hg}$, were determined by an inductively coupled plasma mass spectrometer (ICP-MS, Thermo Fisher Corporation, Munich, Germany).

\subsection{Study Materials}

PS was obtained from a closed pig slurry collection system. Pig manure, urine and partial flushing water entered the pretreatment tank system through pipelines. After anaerobically fermenting for 6 months, this substance was used in this study. Treated PS contained the following trace elements: $0.246 \mathrm{mg} \cdot \mathrm{L}^{-1} \mathrm{Cu}, 0.577 \mathrm{mg} \cdot \mathrm{L}^{-1} \mathrm{Zn}, 0.041 \mathrm{mg} \cdot \mathrm{L}^{-1} \mathrm{~Pb},<5.0 \times 10^{-4} \mathrm{mg} \cdot \mathrm{L}^{-1} \mathrm{Cd}, 0.063 \mathrm{mg} \cdot \mathrm{L}^{-1} \mathrm{Cr}$, $0.0283 \mathrm{mg} \cdot \mathrm{L}^{-1}$ As and $<5 \times 10^{-4} \mathrm{mg} \cdot \mathrm{L}^{-1} \mathrm{Hg}$. The contents of trace elements in PS conform to the national standards of the irrigation water quality in China (GB5084-92) [28]. The total nitrogen, alkali hydrolysable $\mathrm{N}$, total $\mathrm{P}_{2} \mathrm{O}_{5}$, total $\mathrm{K}_{2} \mathrm{O}$ and $\mathrm{pH}$ of PS were $1000 \mathrm{mg} \cdot \mathrm{L}^{-1}, 540 \mathrm{mg} \cdot \mathrm{L}^{-1}, 77.9 \mathrm{mg} \cdot \mathrm{L}^{-1}$, $416 \mathrm{mg} \cdot \mathrm{L}^{-1}$ and 7.92 , respectively. The rice variety in all the treatments was Huaidao No. 5.

\subsection{Field Experiment}

The experiment included 11 treatments with three replicates of each treatment (Table 1), including one unfertilized control treatment (CK1), one local conventional fertilization treatment (CK2) consisting of $150 \mathrm{~kg} \cdot \mathrm{hm}^{-2}$ urea, $225 \mathrm{~kg} \cdot \mathrm{hm}^{-2}$ compound fertilizer $\left(\mathrm{N}: \mathrm{P}_{2} \mathrm{O}_{5}: \mathrm{K}_{2} \mathrm{O}=12: 15: 18\right)$ as base fertilizer, $112.5 \mathrm{~kg} \cdot \mathrm{hm}^{-2}$ urea as tillering fertilizer and $150 \mathrm{~kg} \cdot \mathrm{hm}^{-2}$ urea as panicle fertilizer [28]. Nine treatments (T1-9) involved the combined application of PS and nitrogen fertilizer, and a randomized block design was employed. For basal fertilizer application, PS was applied at a dose of 60, 90 and $120 \mathrm{~m}^{3} \cdot \mathrm{hm}^{-2}$. At the panicle fertilizer stage, PS was applied at a dose of 60,90 and $120 \mathrm{~m}^{3} \cdot \mathrm{hm}^{-2}$. At the tillering stage, urea was applied at a dose of $225 \mathrm{~kg} \cdot \mathrm{hm}^{-2}$. The area of each block was $15.75 \mathrm{~m}^{2}$ ( $4.5 \mathrm{~m}$ long $\times 3.5 \mathrm{~m}$ wide). The direct sowing rate was $112.5 \mathrm{~kg} \cdot \mathrm{hm}^{2}$, and broadcast sowing was adopted. PS as basal fertiliser was applied on 16 June 2013 to allow soil to fully absorb nutrients ahead of seeding, and seeds were sown on 19 June 2013. The management of pests, diseases and weeds was performed using typical local procedures.

Table 1. Design of the field experiment.

\begin{tabular}{|c|c|c|c|}
\hline Treatment & $\begin{array}{l}\text { Pig Slurry as Basal } \\
\text { Fertilizer }\left(\mathrm{m}^{3} \cdot \mathrm{hm}^{-2}\right)\end{array}$ & $\begin{array}{l}\text { Pig Slurry as Panicle } \\
\text { Fertilizer }\left(\mathrm{m}^{3} \cdot \mathrm{hm}^{-2}\right)\end{array}$ & $\begin{array}{l}\text { Total Amount of Pig } \\
\text { Slurry }\left(\mathrm{m}^{3} \cdot \mathrm{hm}^{-2}\right)\end{array}$ \\
\hline $\mathrm{T} 1$ & 60 & 60 & 120 \\
\hline $\mathrm{T} 2$ & 60 & 90 & 150 \\
\hline T3 & 60 & 120 & 180 \\
\hline $\mathrm{T} 4$ & 90 & 60 & 150 \\
\hline T5 & 90 & 90 & 180 \\
\hline T6 & 90 & 120 & 210 \\
\hline T7 & 120 & 60 & 180 \\
\hline T8 & 120 & 90 & 210 \\
\hline T9 & 120 & 120 & 240 \\
\hline $\mathrm{CK} 1^{\mathrm{a}}$ & 0 & 0 & 0 \\
\hline $\mathrm{CK} 2^{\mathrm{b}}$ & 0 & 0 & 0 \\
\hline
\end{tabular}

${ }^{a}$ Zero fertilizer and pig slurry treatment designated as CK1 for basic evaluation of soil fertility; ${ }^{\mathrm{b}}$ Conventional chemical fertilizer treatment designated as CK2 for field production control. 


\subsection{Determination of Trace Elements}

A total of 10 rice plants were collected from each group at the jointing, heading and mature stages, and the dry weight of each component was determined by oven-drying at $70{ }^{\circ} \mathrm{C}$ to a constant weight. Oven-dried samples were then ground in a stainless steel grinder fitted with a 45-mesh sieve to determine the trace element content in the grain or other parts of the rice plant. Samples were digested using a CEM closed microwave system as follows: $0.48 \mathrm{~g}$ samples in nitric acid were digested for 5, 10 and $15 \mathrm{~min}$ at 100,150 and $180^{\circ} \mathrm{C}$. The concentrations of trace elements in the extract, namely, $\mathrm{Pb}$, $\mathrm{Cr}, \mathrm{Co}, \mathrm{Ni}, \mathrm{Cu}, \mathrm{Zn}, \mathrm{Fe}, \mathrm{Mn}$, were measured using an inductively coupled plasma mass spectrometer (ICP-MS, Thermo Fisher Corporation, Munich, Germany).

For all elements tested, the average translocation factor (TF) from straw to grain was calculated as ratios between grain element levels and straw element levels [31].

\subsection{Determination of Rice Yield and Grain Quality}

Rice grain was harvested from an area of $2.25 \mathrm{~m}^{2}$ in each plot and adjusted to a moisture content of $14 \%$. Aboveground biomass and yield were determined for plants sampled randomly from a $1-\mathrm{m}^{2}$ area (excluding the border region) in each plot. Evaluation of rice quality was conducted according to the China national standard for grain quality measurements (GB/T 17891-1999; Supervising Department of Quality and Technology of China, 1999) [32], and all analyses were carried out in duplicate. Grains were dehulled to produce brown rice using a chaff removal machine (OHYA-25, Ohya Corporation, Tokyo, Japan) and the percentage of brown rice was determined. Brown rice was milled with a rice polishing machine (JMNJ-3/CPC 96-3, Hangzhou Qianjiang Instrument Corporation, Hangzhou, China) until a standard degree of milling was achieved (as estimated by the percentage of milled rice and head rice).

Milled rice samples were then oven-dried at $60^{\circ} \mathrm{C}$ to a constant weight and ground with a stainless steel grinder (FW-100, Shanghai Chuding Instrument Corporation, Shanghai, China) fitted with a 100-mesh sieve to prepare samples for protein content, amylose content, gel consistency and starch viscosity analysis.

Amylose and protein contents were measured with an Infratec 1241 grain analyser (FOSS Tecator, Copenhagen, Denmark) and a near-infrared transmittance analyser, respectively, and calculated based on grain dry weight. Gel consistency was measured by the length of cold milled rice paste in a test tube in a horizontal position. Gelatinization temperature and starch viscosity were determined with a rapid visco analyser (RVA) (RVA-3D, Newport Scientific Inc., Warriewood, Australia) using procedures of the American Association of Cereal Chemists (AACC, 1995).

\subsection{Statistical Analysis}

Analysis of variance was performed using the SAS/STAT statistical analysis package (version 6.12, SAS Institute, Cary, NC, USA). Data from each sampling date were analyzed separately and met all requirements for analysis of variance. Differences between means were tested using the least significant difference test at the 0.05 probability level.

\section{Results}

\subsection{Effects of Pig Slurry on Direct-Seeding Rice Biomass}

After application of varying amounts of PS as basal and heading fertilizer, the yield and dry matter accumulation of straw at the maturing stage were highest with the highest PS dosage (T9 treatment). When applying a low dose of PS $\left(60 \mathrm{~m}^{3} \cdot \mathrm{hm}^{-2}\right)$ as basal fertilizer (T1, T2 and T3), the yield decreased by $15.1 \%, 9.4 \%$ and $2.9 \%$, respectively, compared with the control CK2 treatment (Table 2). Application of a medium dosage $\left(90 \mathrm{~m}^{3} \cdot \mathrm{hm}^{-2}\right)$ as basal fertilizer, combined with a low (T4) and medium (T5) dosage as panicle fertilizer decreased the yield by only $9.8 \%$ and $4.8 \%$, respectively. However, application of a high dosage of PS $\left(120 \mathrm{~m}^{3} \cdot \mathrm{hm}^{-2}\right)$ as basal fertilizer, combined with a medium (T8) and high (T9) 
dosage as panicle fertilizer resulted in a yield that was $0.3 \%$ and $6.6 \%$ higher, respectively, than that achieved in CK2. Application of PS at $210 \mathrm{~m}^{3} \cdot \mathrm{hm}^{-2}$ or more during the heading stage (T6, T8 and T9) therefore increased grain yield in direct-seeding rice. Effects of PS on dry matter accumulation of rice straw at the maturing stage displayed a similar pattern. When applied with the same dosage of PS as basal fertilizer, dry matter accumulation of rice straw also increased with the dosage of PS as panicle fertilizer.

Table 2. Aboveground plant biomass production among pig slurry treatments $\left(\mathrm{kg} \cdot \mathrm{hm}^{-2}\right)$.

\begin{tabular}{ccc}
\hline Treatment & Straw & Grain \\
\hline T1 & $7184.69 \pm 188.27 \mathrm{~g}$ & $6542.00 \pm 201.22 \mathrm{f}$ \\
T2 & $7454.74 \pm 261.03 \mathrm{e}$ & $6979.55 \pm 239.57 \mathrm{e}$ \\
T3 & $7581.56 \pm 212.89 \mathrm{~d}$ & $7479.55 \pm 267.31 \mathrm{c}$ \\
T4 & $7216.14 \pm 181.15 \mathrm{f}$ & $6948.25 \pm 236.19 \mathrm{e}$ \\
T5 & $7447.43 \pm 281.67 \mathrm{e}$ & $7333.70 \pm 287.34 \mathrm{~d}$ \\
T6 & $7837.75 \pm 260.56 \mathrm{c}$ & $7771.20 \pm 314.73 \mathrm{~b}$ \\
T7 & $7418.24 \pm 377.64 \mathrm{e}$ & $7427.45 \pm 287.45 \mathrm{c}$ \\
T8 & $8136.09 \pm 253.35 \mathrm{~b}$ & $7729.55 \pm 290.82 \mathrm{~b}$ \\
T9 & $8244.99 \pm 391.41 \mathrm{a}$ & $8210.80 \pm 342.61 \mathrm{a}$ \\
CK1 & $5847.55 \pm 167.39 \mathrm{~h}$ & $6510.75 \pm 235.95 \mathrm{f}$ \\
CK2 & $7549.47 \pm 260.62 \mathrm{~d}$ & $7704.50 \pm 276.17 \mathrm{~b}$
\end{tabular}

Different letters in a column indicate significant differences between PS treatments at the 0.05 level.

\subsection{Effects of Pig Slurry on Trace Element Accumulation in Rice at Different Growth Stages}

The $\mathrm{Cr}, \mathrm{Co}, \mathrm{Ni}, \mathrm{Cu}, \mathrm{Zn}, \mathrm{Fe}$ and $\mathrm{Mn}$ contents in rice plants decreased gradually from the jointing stage to maturing stage, as the reproductive period advanced, whereas $\mathrm{Pb}$ showed the opposite trend (Figures 1 and 2). $\mathrm{Pb}, \mathrm{Cu}, \mathrm{Zn}, \mathrm{Fe}$ and $\mathrm{Mn}$ were lowest in the CK1 treatment and highest in the T9 treatment. At the jointing, heading and maturing stages, $\mathrm{Pb}$ was $84.9 \%, 121.4 \%$ and $61.3 \%$ higher in T9 than in CK1, respectively, while $\mathrm{Cu}$ was increased by $41 \%, 65.7 \%$ and $86.6 \%$, $\mathrm{Zn}$ was increased by $59.6 \%, 97.2 \%$ and $64.0 \%$, Fe was increased by $79.9 \%, 59.4 \%$ and $55.2 \%$, and Mn was increased $60.71 \%$, $76.57 \%$ and $41.20 \%$. At the jointing, heading and maturing stages, when comparing T9 with CK2, the $\mathrm{Pb}$ content was increased by $26.1 \%, 39.1 \%$ and $17.5 \%$, respectively, $\mathrm{Cu}$ was increased by $0.81 \%, 12.8 \%$ and $28.2 \%$, Zn was increased by $0.7 \%, 13.8 \%$ and $9.9 \%$, Fe was increased by $0.38 \%, 12.5 \%$ and $14.4 \%$, whereas Mn was decreased by $3.83 \%, 8.33 \%$ and $4.96 \%$. The amount of these elements increased with increasing application of PS as basal fertiliser during the heading stage, and levels were significantly higher in T6, T8 and T9 than in CK2. In contrast, $\mathrm{Cr}$, $\mathrm{Co}$, Ni were highest in CK2, followed by CK1, and levels of these elements decreased with increasing PS application. In conclusion, the uptake evolution differentiates the micronutrients $(\mathrm{Cu}, \mathrm{Zn}, \mathrm{Fe}$ and $\mathrm{Mn})$ from the non-essential elements $(\mathrm{Cr}, \mathrm{Co}, \mathrm{Ni})$ with the exception of $\mathrm{Pb}$, which "acts" as a micronutrient.

\subsection{Trace Element Content and Translocation in Grains}

Under these experimental conditions, CK1 had the lowest levels of all elements tested, but trace elements were all within the acceptable range for food security prescribed by the government. T9 treatment had the highest levels of $\mathrm{Pb}, \mathrm{Cu}, \mathrm{Zn}$ and $\mathrm{Fe}$, followed by T6 and T8 (Table 3). These results indicate that there is a risk of these elements rising to high levels when PS is applied at over $210 \mathrm{~m}^{3} \cdot \mathrm{hm}^{-2}$. The highest $\mathrm{Cr}, \mathrm{Co}, \mathrm{Ni}$ and Mn contents in grain occurred with conventional fertilizer treatment, and levels in PS treatments were $4.1 \%-32.7 \%, 4.2 \%-141.0 \%, 34.0 \%-186.2 \%$ and $2.0 \%-26.6 \%$ lower, respectively, than those in the CK2 treatment. The results showed that PS can alleviate the toxicity of some heavy metals. Specifically, Cr, Co and Ni contents decreased with increasing application of PS at the heading stage, whereas Mn levels increased.

Linear regression analysis was carried out on the total amount of PS applied and the content of each metal element in rice for all nine PS treatments. The results showed a significant positive 
correlation between the contents of $\mathrm{Pb}, \mathrm{Cu}, \mathrm{Zn}, \mathrm{Fe}$ and $\mathrm{Mn}$ and the amount of PS applied $\left(r=0.945^{* *}\right.$, $\left.0.945^{* *}, 0.834^{* *}, 0.954^{* *}, 0.962^{* *}\right)$. Conversely, there was a significant negative correlation between the contents of $\mathrm{Cr}, \mathrm{Co}$ and $\mathrm{Ni}$ and the amount of PS applied $\left(r=0.968^{* *}, 0.927^{* *}, 0.951^{* *}\right)$.

For all elements tested, the average transfer factor (TF) in PS treatments was 0.475, 0.441, 0.379 and 0.339 , respectively (Table 4). The TFs of $\mathrm{Pb}, \mathrm{Zn}, \mathrm{Cr}$ and $\mathrm{Cu}$ from straw to grain were highest, followed by $\mathrm{Co}, \mathrm{Fe}$ and $\mathrm{Ni}$, and the lowest was $\mathrm{Mn}$ with an average TF of only 0.018 . These trace elements, especially $\mathrm{Mn}$, therefore accumulated in straw instead of grain, and the TF values were significantly different in PS treatments, except for Mn. The TF of $\mathrm{Cr}$ and $\mathrm{Zn}$ increased with increasing PS application at the heading stage, while other elements showed the opposite trend. The highest $\mathrm{TFs}$ of $\mathrm{Pb}, \mathrm{Cr}, \mathrm{Co}, \mathrm{Ni}$ and $\mathrm{Cu}$ from straw to grain were reached in $\mathrm{CK} 2$, followed by PS treatments, and TF values were lowest in CK1. In contrast, the highest TFs of Zn, Fe and Mn were observed in CK1, followed by PS treatments and then CK2. These results suggest PS could alleviate the transfer of $\mathrm{Pb}, \mathrm{Cr}, \mathrm{Co}, \mathrm{Ni}$ and $\mathrm{Cu}$ from straw to grain and enhance the transport of $\mathrm{Zn}$, Fe and $\mathrm{Mn}$ to rice grain, compared with the $\mathrm{CK} 2$ treatment.

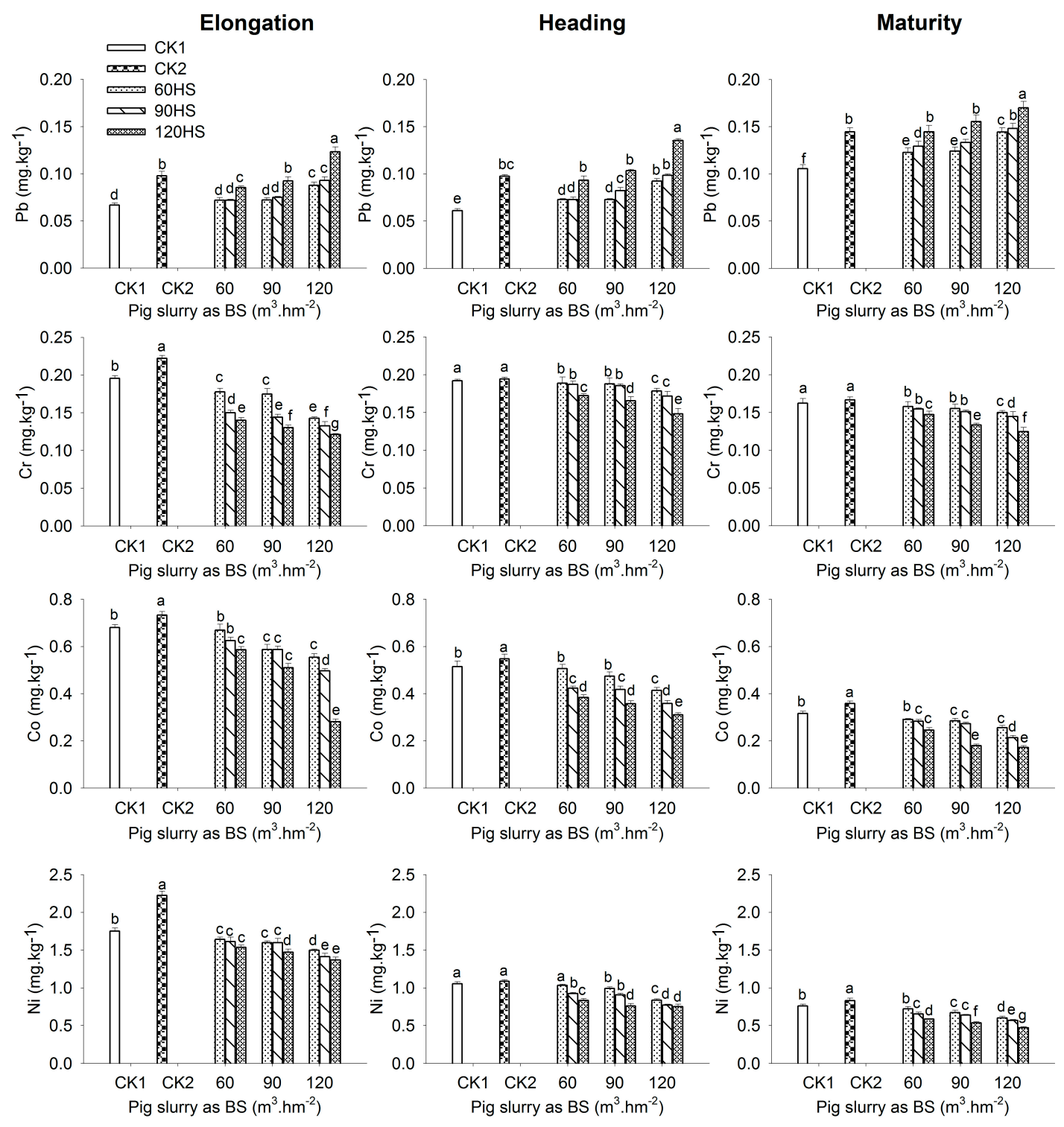

Figure 1. $\mathrm{Pb}, \mathrm{Cr}, \mathrm{Co}$ and $\mathrm{Ni}$ concentrations in plants after the application of PS at different growth stages. Different letters indicate significant differences between PS treatments at the 0.05 level; the bars are standard errors. 

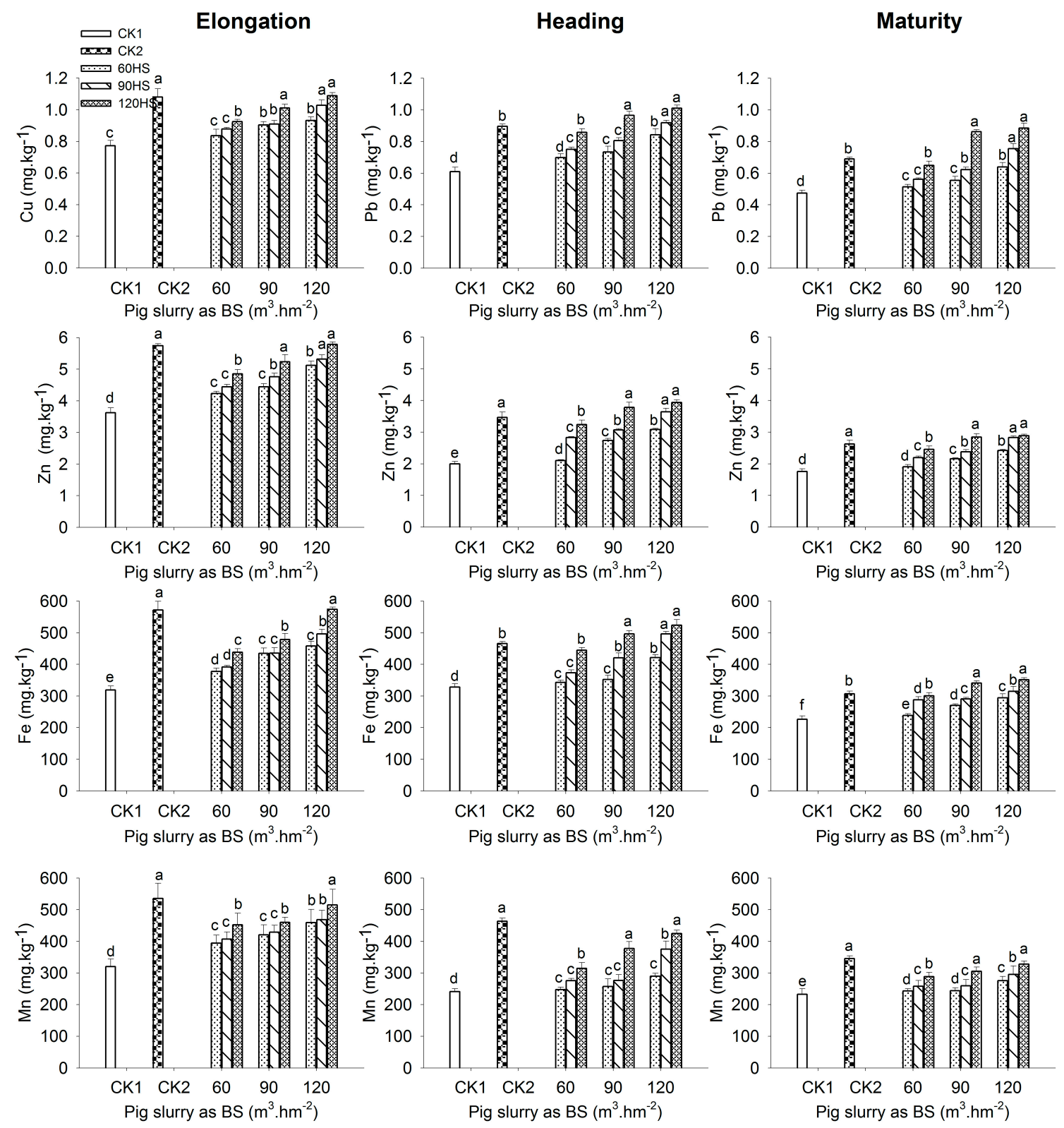

Figure 2. $\mathrm{Cu}, \mathrm{Zn}, \mathrm{Fe}$ and $\mathrm{Mn}$ concentrations in plants after the application of PS at different growth stages. Different letters indicate significant differences between PS treatments at the 0.05 level; the bars are standard errors. 
Table 3. Contents of trace element in grains under different PS treatments $\left(\mathrm{mg}^{\mathrm{kg}} \mathrm{kg}^{-1}\right)$.

\begin{tabular}{|c|c|c|c|c|c|c|c|c|}
\hline Treatments & $\mathrm{Pb}$ & $\mathrm{Cr}$ & Co & $\mathrm{Ni}$ & $\mathrm{Cu}$ & $\mathrm{Zn}$ & $\mathrm{Fe}$ & Mn \\
\hline $\mathrm{T} 1$ & $0.0617 \pm 0.0012 b$ & $0.0632 \pm 0.0018 a$ & $0.0710 \pm 0.0018 \mathrm{a}$ & $0.0927 \pm 0.0029 \mathrm{~b}$ & $0.2083 \pm 0.0096 a$ & $0.9646 \pm 0.0401 \mathrm{c}$ & $33.8 \pm 1.1 \mathrm{~cd}$ & $4.383 \pm 0.158 c$ \\
\hline $\mathrm{T} 2$ & $0.0662 \pm 0.0013 a$ & $0.0592 \pm 0.0029 c$ & $0.0606 \pm 0.0016 b$ & $0.0762 \pm 0.0034 b c$ & $0.2098 \pm 0.0036 a$ & $0.9925 \pm 0.0257 c$ & $34.4 \pm 1.3 c$ & $4.804 \pm 0.203 b$ \\
\hline T3 & $0.0672 \pm 0.0015 a$ & $0.0532 \pm 0.0024 \mathrm{f}$ & $0.0512 \pm 0.0018 c$ & $0.0677 \pm 0.0029 c$ & $0.2191 \pm 0.0108 a$ & $1.0337 \pm 0.0224 b c$ & $36.9 \pm 0.4 b$ & $5.003 \pm 0.123 b$ \\
\hline $\mathrm{T} 4$ & $0.0643 \pm 0.0031 \mathrm{a}$ & $0.0602 \pm 0.0009 b$ & $0.0707 \pm 0.0024 \mathrm{a}$ & $0.0812 \pm 0.0028 b c$ & $0.2087 \pm 0.0075 a$ & $0.9691 \pm 0.0256 c$ & $33.9 \pm 1.9 \mathrm{~d}$ & $4.585 \pm 0.094 c$ \\
\hline T5 & $0.0664 \pm 0.0017 \mathrm{a}$ & $0.0562 \pm 0.0024 \mathrm{~d}$ & $0.0604 \pm 0.0029 b$ & $0.0668 \pm 0.0032 c$ & $0.2162 \pm 0.0105 a$ & $1.0050 \pm 0.0283 c$ & $35.8 \pm 0.8 \mathrm{c}$ & $4.946 \pm 0.195 \mathrm{~b}$ \\
\hline T6 & $0.0679 \pm 0.0027 a$ & $0.0506 \pm 0.0006 \mathrm{~g}$ & $0.0327 \pm 0.0016 c$ & $0.0441 \pm 0.0015 d$ & $0.2373 \pm 0.0078 a$ & $1.2883 \pm 0.0568 \mathrm{ab}$ & $38.3 \pm 1.5 a$ & $5.110 \pm 0.114 b$ \\
\hline $\mathrm{T} 7$ & $0.0669 \pm 0.0028 \mathrm{a}$ & $0.0553 \pm 0.0014 \mathrm{e}$ & $0.0569 \pm 0.0011 b$ & $0.0682 \pm 0.0024 c$ & $0.2178 \pm 0.0047 a$ & $1.0079 \pm 0.0182 c$ & $35.8 \pm 0.5 c$ & $4.960 \pm 0.127 c$ \\
\hline $\mathrm{T} 8$ & $0.0679 \pm 0.0022 \mathrm{a}$ & $0.0521 \pm 0.0008 \mathrm{f}$ & $0.0455 \pm 0.0014 c$ & $0.0629 \pm 0.0023 \mathrm{~cd}$ & $0.2369 \pm 0.0041 \mathrm{a}$ & $1.0675 \pm 0.0238 b c$ & $38.1 \pm 1.8 \mathrm{a}$ & $5.058 \pm 0.232 b$ \\
\hline T9 & $0.0723 \pm 0.0012 \mathrm{a}$ & $0.0496 \pm 0.0023 \mathrm{~g}$ & $0.0307 \pm 0.0009 c$ & $0.0434 \pm 0.0007 \mathrm{~d}$ & $0.2463 \pm 0.0038 \mathrm{a}$ & $1.3632 \pm 0.0271 \mathrm{a}$ & $38.7 \pm 0.5 \mathrm{a}$ & $5.442 \pm 0.188 \mathrm{a}$ \\
\hline CK1 & $0.0565 \pm 0.0021 b$ & $0.0646 \pm 0.0017 \mathrm{a}$ & $0.0738 \pm 0.0012 \mathrm{a}$ & $0.0952 \pm 0.0026 b$ & $0.1616 \pm 0.0079 b$ & $0.9196 \pm 0.0236 c$ & $33.4 \pm 0.9 \mathrm{~d}$ & $4.267 \pm 0.071 \mathrm{~d}$ \\
\hline CK2 & $0.0677 \pm 0.0008 a$ & $0.0658 \pm 0.0028 a$ & $0.0740 \pm 0.0029 a$ & $0.1242 \pm 0.0045 \mathrm{a}$ & $0.2258 \pm 0.0049 a$ & $1.0427 \pm 0.0468 \mathrm{bc}$ & $37.2 \pm 0.7 \mathrm{~b}$ & $5.550 \pm 0.215 a$ \\
\hline
\end{tabular}

Different letters in a column indicate significant differences between PS treatments at the 0.05 level.

Table 4. Translocation factors (TFs) of trace elements from straw to grain.

\begin{tabular}{|c|c|c|c|c|c|c|c|c|}
\hline Treatments & $\mathrm{Pb}$ & $\mathrm{Cr}$ & Co & $\mathrm{Ni}$ & $\mathrm{Cu}$ & Zn & $\mathrm{Fe}$ & Mn \\
\hline $\mathrm{T} 1$ & $0.512 \pm 0.014 b$ & $0.361 \pm 0.013 c$ & $0.244 \pm 0.002 b$ & $0.128 \pm 0.002 b$ & $0.406 \pm 0.003 a$ & $0.420 \pm 0.017 \mathrm{e}$ & $0.142 \pm 0.007 \mathrm{~b}$ & $0.019 \pm 0.001 a$ \\
\hline $\mathrm{T} 2$ & $0.502 \pm 0.018 c$ & $0.383 \pm 0.011 b$ & $0.214 \pm 0.006 \mathrm{~d}$ & $0.116 \pm 0.007 c$ & $0.374 \pm 0.012 b$ & $0.452 \pm 0.005 d$ & $0.123 \pm 0.004 c$ & $0.018 \pm 0.001 a$ \\
\hline T3 & $0.464 \pm 0.022 \mathrm{~d}$ & $0.400 \pm 0.017 a$ & $0.209 \pm 0.001 \mathrm{e}$ & $0.116 \pm 0.003 c$ & $0.338 \pm 0.014 c$ & $0.506 \pm 0.002 b$ & $0.120 \pm 0.001 c$ & $0.017 \pm 0.001 a$ \\
\hline $\mathrm{T} 4$ & $0.518 \pm 0.005 b$ & $0.372 \pm 0.012 b c$ & $0.248 \pm 0.005 b$ & $0.121 \pm 0.003 b$ & $0.377 \pm 0.009 b$ & $0.423 \pm 0.018 \mathrm{e}$ & $0.126 \pm 0.001 c$ & $0.019 \pm 0.001 a$ \\
\hline T5 & $0.497 \pm 0.012 c$ & $0.379 \pm 0.014 b$ & $0.222 \pm 0.004 c$ & $0.104 \pm 0.004 \mathrm{e}$ & $0.348 \pm 0.009 c$ & $0.448 \pm 0.006 \mathrm{~d}$ & $0.123 \pm 0.005 c$ & $0.019 \pm 0.001 a$ \\
\hline T6 & $0.437 \pm 0.013 f$ & $0.388 \pm 0.013 b$ & $0.182 \pm 0.003 f$ & $0.082 \pm 0.004 \mathrm{f}$ & $0.275 \pm 0.007 f$ & $0.453 \pm 0.002 \mathrm{~d}$ & $0.121 \pm 0.001 c$ & $0.017 \pm 0.001 a$ \\
\hline $\mathrm{T} 7$ & $0.463 \pm 0.017 \mathrm{~d}$ & $0.361 \pm 0.004 c$ & $0.223 \pm 0.003 c$ & $0.113 \pm 0.004 \mathrm{~cd}$ & $0.341 \pm 0.014 c$ & $0.377 \pm 0.012 \mathrm{~g}$ & $0.122 \pm 0.006 c$ & $0.018 \pm 0.001 a$ \\
\hline $\mathrm{T} 8$ & $0.458 \pm 0.015 \mathrm{e}$ & $0.369 \pm 0.016 c$ & $0.213 \pm 0.006 \mathrm{~d}$ & $0.111 \pm 0.004 \mathrm{~d}$ & $0.314 \pm 0.019 \mathrm{e}$ & $0.416 \pm 0.004 \mathrm{e}$ & $0.121 \pm 0.002 c$ & $0.017 \pm 0.001 a$ \\
\hline T9 & $0.425 \pm 0.024 \mathrm{f}$ & $0.398 \pm 0.017 a$ & $0.178 \pm 0.007 \mathrm{f}$ & $0.092 \pm 0.003 \mathrm{f}$ & $0.279 \pm 0.013 \mathrm{f}$ & $0.473 \pm 0.001 c$ & $0.110 \pm 0.004 \mathrm{~d}$ & $0.017 \pm 0.001 a$ \\
\hline CK1 & $0.468 \pm 0.017 \mathrm{~d}$ & $0.395 \pm 0.009 a$ & $0.207 \pm 0.006 \mathrm{e}$ & $0.125 \pm 0.002 b$ & $0.327 \pm 0.015 \mathrm{~d}$ & $0.523 \pm 0.015 a$ & $0.148 \pm 0.001 a$ & $0.020 \pm 0.001 a$ \\
\hline CK2 & $0.536 \pm 0.009 a$ & $0.403 \pm 0.008 a$ & $0.254 \pm 0.002 \mathrm{a}$ & $0.149 \pm 0.005 a$ & $0.341 \pm 0.005 c$ & $0.397 \pm 0.007 f$ & $0.119 \pm 0.002 c$ & $0.016 \pm 0.001 a$ \\
\hline
\end{tabular}

Different letters in a column indicate significant differences between PS treatments at the 0.05 level 


\subsection{Processing, Eating and Cooking Quality of Grain}

In direct-seeding rice, processing quality parameters including brown rice, milled rice and head milled rice all tended to be highest in CK2, intermediate in PS treatments, and lowest in CK1 (Table 5). Brown rice in PS treatments was not significantly different from CK2, but milled and head milled rice increased with increasing PS application for all treatments except T9, and the difference compared to CK2 was significant.

Table 5. Processing, cooking and eating quality of rice grains under different PS treatments.

\begin{tabular}{ccccccc}
\hline Treatments & $\begin{array}{c}\text { Brown Rice } \\
\mathbf{( \% )}\end{array}$ & $\begin{array}{c}\text { Milled Rice } \\
\mathbf{( \% )}\end{array}$ & $\begin{array}{c}\text { Head Milled Rice } \\
\mathbf{( \% )}\end{array}$ & $\begin{array}{c}\text { Protein Content } \\
\mathbf{( \% )}\end{array}$ & $\begin{array}{c}\text { Amylose Content } \\
\mathbf{( \% )}\end{array}$ & $\begin{array}{c}\text { Gel Consistency } \\
(\mathbf{m m})\end{array}$ \\
\hline T1 & $85.3 \pm 2.2 \mathrm{~b}$ & $79.5 \pm 1.5 \mathrm{c}$ & $75.1 \pm 3.2 \mathrm{~cd}$ & $8.8 \pm 0.4 \mathrm{c}$ & $18.4 \pm 0.3 \mathrm{ab}$ & $64.0 \pm 1.2 \mathrm{~b}$ \\
T2 & $85.4 \pm 1.4 \mathrm{ab}$ & $81.0 \pm 2.4 \mathrm{c}$ & $76.1 \pm 1.9 \mathrm{~cd}$ & $9.0 \pm 0.2 \mathrm{abc}$ & $18.1 \pm 0.9 \mathrm{abc}$ & $64.5 \pm 2.7 \mathrm{~b}$ \\
T3 & $85.4 \pm 4.0 \mathrm{ab}$ & $85.6 \pm 3.5 \mathrm{bc}$ & $78.5 \pm 3.9 \mathrm{bc}$ & $9.1 \pm 0.3 \mathrm{abc}$ & $17.3 \pm 0.7 \mathrm{bcd}$ & $66.0 \pm 2.7 \mathrm{~b}$ \\
T4 & $85.4 \pm 2.2 \mathrm{ab}$ & $79.9 \pm 3.4 \mathrm{c}$ & $75.8 \pm 3.6 \mathrm{~cd}$ & $8.9 \pm 0.4 \mathrm{bc}$ & $17.7 \pm 0.4 \mathrm{abcd}$ & $64.5 \pm 1.3 \mathrm{~b}$ \\
T5 & $85.4 \pm 1.6 \mathrm{ab}$ & $82.6 \pm 2.5 \mathrm{bc}$ & $78.3 \pm 2.5 \mathrm{bcd}$ & $9.0 \pm 0.1 \mathrm{abc}$ & $17.5 \pm 0.8 \mathrm{abcd}$ & $64.0 \pm 3.2 \mathrm{~b}$ \\
T6 & $85.6 \pm 2.1 \mathrm{ab}$ & $87.1 \pm 1.8 \mathrm{bc}$ & $81.8 \pm 3.4 \mathrm{~b}$ & $9.3 \pm 0.2 \mathrm{ab}$ & $17.3 \pm 0.6 \mathrm{bcd}$ & $70.0 \pm 1.5 \mathrm{a}$ \\
T7 & $85.4 \pm 1.7 \mathrm{ab}$ & $82.9 \pm 3.3 \mathrm{bc}$ & $78.4 \pm 1.9 \mathrm{bcd}$ & $9.0 \pm 0.4 \mathrm{abc}$ & $17.4 \pm 0.8 \mathrm{bcd}$ & $64.5 \pm 1.4 \mathrm{~b}$ \\
T8 & $85.5 \pm 3.2 \mathrm{ab}$ & $86.0 \pm 3.7 \mathrm{bc}$ & $79.4 \pm 1.2 \mathrm{bc}$ & $9.1 \pm 0.4 \mathrm{abc}$ & $16.8 \pm 0.7 \mathrm{~cd}$ & $71.0 \pm 1.0 \mathrm{a}$ \\
T9 & $85.9 \pm 3.1 \mathrm{ab}$ & $88.3 \pm 4.2 \mathrm{ab}$ & $82.9 \pm 2.2 \mathrm{~b}$ & $9.4 \pm 0.4 \mathrm{a}$ & $16.8 \pm 0.2 \mathrm{~d}$ & $71.5 \pm 2.6 \mathrm{a}$ \\
CK1 & $84.5 \pm 3.8 \mathrm{c}$ & $79.5 \pm 1.4 \mathrm{c}$ & $74.0 \pm 2.3 \mathrm{~d}$ & $8.7 \pm 0.3 \mathrm{c}$ & $18.6 \pm 0.5 \mathrm{a}$ & $60.0 \pm 2.2 \mathrm{c}$ \\
CK2 & $86.1 \pm 0.9 \mathrm{a}$ & $88.7 \pm 4.1 \mathrm{a}$ & $83.0 \pm 1.2 \mathrm{a}$ & $9.2 \pm 0.4 \mathrm{ab}$ & $18.5 \pm 0.4 \mathrm{a}$ & $71.0 \pm 1.5 \mathrm{a}$ \\
\hline
\end{tabular}

Different letters in a column indicate significant differences between PS treatments at the 0.05 level.

The highest amylose content was observed in CK1, followed by CK2, and differences from most PS treatments were significant (Table 5). The amylose content decreased with increasing PS application at the heading stage when PS was also used as basal fertilizer. The gel consistency was significantly lower in CK1 than in other treatments, and highest in T9, which was $19.2 \%$ and $0.7 \%$ higher than in CK1 and CK2, respectively, and $0.7 \%-11.7 \%$ higher than in other PS treatments.

The protein content was lowest in CK1 but the difference with most PS treatments was not significant (Table 5), while the highest protein content in grains was reached in T9 $(8.5 \%$ and $1.4 \%$ higher than CK1 and CK2, respectively), followed by T6. The protein content increased with increasing PS application at the heading stage when PS was also used as basal fertilizer. When applying a low dosage of PS as basal fertilizer, the protein content did not differ significantly no matter how much PS was applied at the heading stage, but when a medium or high dosage of PS was applied as basal fertilizer, a high or medium dosage of PS as panicle fertilizer resulted in a significant increase in protein content.

\subsection{Starch Pasting Properties}

The starch pasting properties of ground grains strongly influences the texture and stickiness of cooked rice, and can be characterized using RVA profiles [32]. Peak viscosity, hot viscosity, cool viscosity, pasting temperature and breakdown were highest in the T9 treatment, as the setback was lowest (Table 6). These parameters all increased with increasing PS application at the heading stage when PS was also used as basal fertilizer, and differences compared with CK2 were significant. 
Table 6. RVA profile characteristics for evaluating starch pasting properties of rice grains under different PS treatments.

\begin{tabular}{|c|c|c|c|c|c|c|}
\hline Treatments & $\begin{array}{l}\text { Peak Viscosity } \\
\text { (cP) }\end{array}$ & $\begin{array}{l}\text { Hot Viscosity } \\
\text { (cP) }\end{array}$ & $\begin{array}{l}\text { Cool Viscosity } \\
\text { (cP) }\end{array}$ & $\begin{array}{l}\text { Pasting Temperature } \\
\qquad\left({ }^{\circ} \mathrm{C}\right)\end{array}$ & $\begin{array}{l}\text { Breakdown } \\
(\mathrm{cP})\end{array}$ & $\begin{array}{l}\text { Setback } \\
\text { (cP) }\end{array}$ \\
\hline $\mathrm{T} 1$ & $2045.3 \pm 23.1 c$ & $1319.7 \pm 34.9 b$ & $2325.7 \pm 34.7 \mathrm{bc}$ & $69.7 \pm 3.3 b$ & $675.0 \pm 16.1 \mathrm{e}$ & $292.0 \pm 5.1 \mathrm{a}$ \\
\hline $\mathrm{T} 2$ & $2085.0 \pm 24.4 b c$ & $1339.0 \pm 53.5 b$ & $2336.7 \pm 82.1 b c$ & $70.0 \pm 2.1 b$ & $720.0 \pm 15.8 \mathrm{c}$ & $266.0 \pm 7.7 \mathrm{~b}$ \\
\hline T3 & $2156.7 \pm 43.5 b c$ & $1390.0 \pm 55.6 b$ & $2369.3 \pm 111.8 b c$ & $70.2 \pm 0.8 b$ & $766.5 \pm 36.4 b$ & $249.0 \pm 6.3 c$ \\
\hline $\mathrm{T} 4$ & $2084.7 \pm 47.6 \mathrm{bc}$ & $1327.0 \pm 41.4 \mathrm{~b}$ & $2331.0 \pm 60.4 b c$ & $69.7 \pm 2.7 \mathrm{~b}$ & $710.5 \pm 29.9 d$ & $274.5 \pm 3.5 b$ \\
\hline T5 & $2098.7 \pm 70.7 b c$ & $1344.0 \pm 36.2 \mathrm{~b}$ & $2344.5 \pm 104.0 \mathrm{bc}$ & $70.0 \pm 2.8 b$ & $733.0 \pm 9.2 \mathrm{c}$ & $257.5 \pm 3.4 b$ \\
\hline T6 & $2204.3 \pm 95.1 \mathrm{ab}$ & $1438.7 \pm 43.5 \mathrm{ab}$ & $2444.0 \pm 42.3 \mathrm{ab}$ & $70.5 \pm 3.3 b$ & $772.0 \pm 35.2 \mathrm{ab}$ & $226.0 \pm 4.8 \mathrm{e}$ \\
\hline $\mathrm{T} 7$ & $2110.7 \pm 87.3 b c$ & $1364.3 \pm 21.3 b$ & $2353.3 \pm 92.5 b c$ & $70.2 \pm 1.2 b$ & $758.0 \pm 25.9 b$ & $255.5 \pm 7.8 b$ \\
\hline $\mathrm{T} 8$ & $2163.3 \pm 23.6 b c$ & $1391.0 \pm 32.7 \mathrm{~b}$ & $2374.0 \pm 102.2 b c$ & $70.3 \pm 2.6 b$ & $770.0 \pm 24.8 \mathrm{ab}$ & $231.0 \pm 8.6 \mathrm{~d}$ \\
\hline $\mathrm{T} 9$ & $2317.3 \pm 89.8 \mathrm{a}$ & $1562.3 \pm 69.8 \mathrm{a}$ & $2558.3 \pm 64.3 \mathrm{a}$ & $78.3 \pm 3.6 \mathrm{a}$ & $791.5 \pm 23.6 \mathrm{a}$ & $199.5 \pm 4.5 f$ \\
\hline CK1 & $2039.0 \pm 75.4 c$ & $1310.3 \pm 20.4 b$ & $2312.3 \pm 98.2 c$ & $69.7 \pm 0.8 b$ & $663.0 \pm 26.7 \mathrm{e}$ & $259.5 \pm 11.2 b$ \\
\hline CK2 & $2109.7 \pm 42.1 b c$ & $1346.7 \pm 33.9 b$ & $2352.0 \pm 87.1 b c$ & $70.2 \pm 3.9 b$ & $753.5 \pm 21.1 b$ & $292.0 \pm 8.1 \mathrm{a}$ \\
\hline
\end{tabular}

Different letters in a column indicate significant differences between PS treatments at the 0.05 level. 


\section{Discussion}

Previous studies indicate that yield, heavy metal content and crop quality are all significantly affected by application of PS during crop production [12,33-35]. Li et al. [11] found that pig manure increased the grain yield between 0.3- and 15.3-fold. In this research, we demonstrated that, when combined with $225 \mathrm{~kg} \cdot \mathrm{hm}^{-2}$ urea at the tillering stage, the yield of high dosage of PS application treatment, T8 and T9, can reach or even exceed the yield of conventional chemical treatment (CK2). In each PS treatment, the chemical N applied was only 41.4 percent of that in CK2, saving 58.6 percent chemical N fertilizer. However, it is worthy to point out that, when the total PS application was 150 $\mathrm{m}^{3} \cdot \mathrm{hm}^{-2}$, the total $\mathrm{N}$ input was $253.5 \mathrm{~kg} \cdot \mathrm{hm}^{-2}$, equal to the CK2 treatment $\left(250 \mathrm{~kg} \cdot \mathrm{hm}^{-2}\right)$. Thus, when the dosage of PS application was 180, 210 and $240 \mathrm{~m}^{3} \cdot \mathrm{hm}^{-2}$, the total load of N exceeded CK2 by $13.4 \%, 25.4 \%$ and $37.4 \%$. Therefore, we caution that when applying PS as fertilizer in rice production, other measures should be taken to avoid ammonia volatilization to the air, and nitrate loss in the water should be altered and avoided.

Successive pig slurry applications may increase soil $\mathrm{Cu}$ and $\mathrm{Zn}$ concentrations and change the proportions of free chemical species in solution when combined with plant cultivation [13]. Additionally, organic fertilization, especially farmyard manure and straw, significantly reduced the cadmium content in selected vegetables [36]. However, when soils were amended with biogas slurry, Bian et al. [37] measured mean concentrations of $\mathrm{Cr}$ of 0.43 and $0.46 \mathrm{mg} \cdot \mathrm{kg}^{-1}$ in rice and wheat, respectively, which are close to the standard limit $\left(0.5 \mathrm{mg} \cdot \mathrm{kg}^{-1}\right)$, and mean concentrations of $\mathrm{Zn}, \mathrm{Pb}$, and $\mathrm{Cd}$ exceeded the maximum permissible levels by 1.8-, 20.7-, and 2.6-fold, respectively. The reason for the apparent contradiction may be due to differences in heavy metal contents in the PS and biogas slurries applied, or differences in soil characteristics between experiments. In the present study, levels of $\mathrm{Ni}$ were highest in both plant material and grain in the CK2 treatment, followed by CK1, and lowest in the nine PS treatments. $\mathrm{Cr}$ and Co were highest in CK2, intermediate in PS treatments, and lowest in CK1, suggesting PS can alleviate toxicity of some heavy metals in direct-seeding rice. The Cr, Co and Ni contents decreased with increasing PS, whereas Pb showed the opposite trend. Even though the $\mathrm{Pb}$ content in grain was lower than the maximum allowed level, it is still important to be mindful of $\mathrm{Pb}$ pollution during long-term $\mathrm{PS}$ utilization.

Microelements such as $\mathrm{Cu}, \mathrm{Zn}, \mathrm{Fe}$ and $\mathrm{Mn}$ are indispensable for plant growth $[11,35]$. When $\mathrm{Cu}$ and $\mathrm{Zn}$ are used as pig feed additives, they can also be found in high concentrations in some animal manures and may be retained in the soil $[15,17]$. It has been shown that $\mathrm{Fe}, \mathrm{Mn}, \mathrm{Cu}$ and $\mathrm{Zn}$ in rapeseed increases with increasing biogas slurry application [38]. Levels of $\mathrm{Zn}$ and $\mathrm{Cu}$ in stems and leaves were significantly higher in all anaerobically digested slurry treatments than in the control chemical fertilizer treatment, whereas comparable concentrations of $\mathrm{Zn}$ and $\mathrm{Cu}$ were observed in the rice grain among the treatments [14]. In our study, $\mathrm{Cu}, \mathrm{Zn}$, and Fe increased with increasing PS application, consistent with a previous report [38]. $\mathrm{Cu}, \mathrm{Zn}$ and Fe decreased gradually from the jointing stage to the maturing stage, with the advancement of the reproductive period, and levels were higher than in the CK1 and CK2 treatments when PS was applied in combination with nitrogen fertilizer. Considering the total load of TE, the input quantities of $\mathrm{Cu}$ and $\mathrm{Zn}$ accompanied by PS were 112.7- and 39.5-fold higher in the T9 treatment when compared with CK2. Therefore, it is reasonable to interpret that contents of $\mathrm{Cu}$ and $\mathrm{Zn}$ were $9.08 \%$ and $30.7 \%$ higher than in the CK2 grains. These results indicate that PS can increase the content of some micronutrient elements in direct-seeding rice, but levels remained below the maximum allowed limits. However, concentrations of these elements in soil should continue to be monitored to avoid environmental pollution.

In previous rice research, less attention has been paid to the effects of PS on processing and eating quality. Liu et al. [39] reported that biogas manure is an effective nutrient source for high-quality vegetable production, based on synergistic effects and its ability to enhance yield and improve quality, and to suppress nitrate accumulation. In the present study, application of PS combined with nitrogen fertilizer decreased the processing quality of direct-seeding rice only slightly, but in our previous study, Gao et al. [28] found that application of PS to machine-transplanted rice enhanced brown, milled 
and head milled rice. Differences in the effects on processing quality may be attributed to different ways nutrients are absorbed under different cultivation methods. Indeed, Zhang et al. [40] found that, compared with machine-transplanted rice, the nutrient absorption pattern of direct-seeding rice is stronger during the early growth stage and weaker during the late growth stage. The underlying mechanisms, however, are not fully understood. Even so, application of PS consistently decreased the amylase content and optimized the RVA profile in both cultivation methods, and therefore improved the overall rice grain quality.

\section{Conclusions}

In conclusion, with a total PS dosage of between 210 and $240 \mathrm{~m}^{3} \cdot \mathrm{hm}^{-2}$ as basal and panicle fertilizer, the yield of direct-seeding rice reached or even exceeded that of regular chemical fertilizer. $\mathrm{The} \mathrm{Pb}$ content increased gradually from the jointing stage to the maturing stage, but levels of many other metal elements decreased following PS application. Specifically, PS mitigated the accumulation of $\mathrm{Cr}, \mathrm{Co}, \mathrm{Ni}$ and $\mathrm{Mn}$, but levels of $\mathrm{Pb}, \mathrm{Cu}, \mathrm{Zn}$ and Fe increased with increasing PS dosage, reaching a peak in treatment T9 $\left(240 \mathrm{~m}^{3} \cdot \mathrm{hm}^{-2}\right)$ that remained below the maximum contaminants allowed in food (GB2762-2005) [29]. Additionally, PS decreased the transfer of $\mathrm{Pb}, \mathrm{Cr}, \mathrm{Co}, \mathrm{Ni}$ and $\mathrm{Cu}$ from vegetative plant parts to grain, but increased the transfer of $\mathrm{Zn}, \mathrm{Fe}$ and Mn. Furthermore, PS had only a slight negative effect on grain processing quality, and significantly decreased the amylose content, enhanced gel consistency, and optimized the RVA profile, and improved the overall quality of direct-seeding rice.

Acknowledgments: This study was supported by the National Natural Science Foundation of China (No. 31201154 and 31571596), Three New Agriculture Project of Jiangsu Province (SXGC[2016]212 and SXGC[2015]089), the Open Project Program of Key Laboratory of Crop Physiology (No. K12008) and the Priority Academic Program Development of Jiangsu Higher Education Institutions.

Author Contributions: Lifen Huang and Hengyang Zhuang conceived and designed the experiments; Wei Gao performed the experiments; Jie Yang and Lifen Huang analyzed the data; Jie Yang contributed reagents/materials/analysis tools; Lifen Huang wrote the paper; Weikang Yang and Xiaoyi Cui revised the paper. All authors read and approved the final manuscript.

Conflicts of Interest: The authors declare no conflict of interest.

\section{References}

1. Zhang, F.S.; Ma, W.Q.; Cen, X.P. Research and Application of Nutrient Resources Integrated Management Technology; China Agricultural University Press: Beijing, China, 2006.

2. Marcato, C.E.; Pinelli, E.; Pouech, P.; Winterton, P.; Guiresse, M. Particle size and metal distributions in anaerobically digested pig slurry. Bioresour. Technol. 2008, 99, 2340-2348. [CrossRef] [PubMed]

3. Brunetto, G.; Comin, J.J.; Schmitt, D.E.; Guardini, R.; Mezzari, C.P.; Oliveira, B.S.; Moraes, M.P.; Gatiboni, L.C.; Lovato, P.E.; Ceretta, C.A. Changes in soil acidity and organic carbon in a sandy typic hapludalf after medium-term pig-slurry and deep-litter application. Rev. Bras. Ciênc. Solo 2012, 36, 1620-1628. [CrossRef]

4. Couto, R.R.; Santos, M.; Comin, J.J.; Pittol Martini, L.C.; Gatiboni, L.C.; Martins, S.R.; Filho, B.P.; Brunetto, G. Environmental vulnerability and phosphorus fractions of areas with pig slurry applied to the soil. J. Environ. Qual. 2015, 44, 162-173. [CrossRef] [PubMed]

5. Guardini, R.; Comin, J.J.; Rheinheimer, D.S.; Gatiboni, L.C.; Tiecher, T.; Schmitt, D.E.; Bender, M.A.; Filho, P.B.; Oliveira, P.A.V.; Brunetto, G. Phosphorus accumulation and pollution potential in a Hapludult fertilized with pig manure. Rev. Bras. Ciênc. Solo 2012, 36, 1333-1342. [CrossRef]

6. Scherer, E.E.; Nesi, C.N.; Massotti, Z. Long-term swine manure fertilization and its effects on soil chemical properties in Santa Catarina, southern Brazil. Rev. Bras. Ciênc. Solo 2010, 34, 1375-1383. [CrossRef]

7. Tao, X.T.; Zhu, Z.J; Gao, W.; Miao, C.Y.; Wang, Y.L.; Huang, L.F.; Zhuang, H.Y.; Lu, J.F. Nitrogen uptake and utilization in wheat as influenced by pig slurry from large-scale pig farm. J. Agro-Environ. Sci. 2014, 33, 555-561. (In Chinese)

8. Gomez-Munoz, B.; Case, S.D.C.; Jensen, L.S. Pig slurry acidification and separation techniques affect soil N and $\mathrm{C}$ turnover and $\mathrm{N}_{2} \mathrm{O}$ emissions from solid, liquid and biochar fractions. J. Environ. Manag. 2016, 168, 236-244. [CrossRef] [PubMed] 
9. Legros, S.; Doelsch, B.; Feder, F.; Moussard, G.; Sansoulet, J.; Gaudet, J.P.; Rigaud, S.; Basile Doelsch, I.; Saint Macary, H.; Bottero, J.Y. Fate and behaviour of $\mathrm{Cu}$ and $\mathrm{Zn}$ from pig slurry spreading in a tropical water-soil-plant system. Agric. Ecosyst. Environ. 2013, 164, 70-79. [CrossRef]

10. Mallmann, F.J.K.; Rheinheimer, D.S.; Ceretta, C.A.; Cella, C.; Minella, J.P.G.; Guma, R.L.; Filipovié, V.; Oort, F.V.; Simunek, J. Soil tillage to reduce surface metal contamination model development and simulations of zinc and copper concentration profiles in a pig slurry-amended soil. Agric. Ecosyst. Environ. 2014, 196, 59-68. [CrossRef]

11. Li, P.; Wang, X.X.; Zhang, T.L.; Zhou, D.M.; He, Y.Q. Effects of several amendments on rice growth and uptake of copper and cadmium from a contaminated soil. J. Environ. Sci. 2008, 20, 449-455. [CrossRef]

12. Jia, Y.; Sun, G.X.; Huang, H.; Zhu, Y.G. Biogas slurry application elevated arsenic accumulation in rice plant through increased arsenic release and methylation in paddy soil. Plant Soil 2013, 365, 387-396. [CrossRef]

13. Ye, X.X.; Sun, B.; Yin, Y.L. Variation of As concentration between soil types and rice genotypes and the selection of cultivars for reducing as in the diet. Chemosphere 2012, 87, 384-389. [CrossRef] [PubMed]

14. Sasada, Y.; Win, K.T.; Nonaka, R.; Win, A.T.; Toyota, K.; Motobayashi, T.; Hosomi, M.; Chen, D.J.; Lu, J. Methane and $\mathrm{N}_{2} \mathrm{O}$ emissions, nitrate concentrations of drainage water, and zinc and copper uptake by rice fertilized with anaerobically digested cattle or pig slurry. Biol. Fertil. Soils 2011, 47, 949-956. [CrossRef]

15. De Conti, L.; Ceretta, C.A.; Ferreira, P.A.A.; Lourenzi, C.R.; Girotto, E.; Lorensini, F.; Tiecher, T.L.; Marchezan, C.; Anchieta, M.G.; Brunetto, G. Soil solution concentrations and chemical species of copper and zinc in a soil with a history of pig slurry application and plant cultivation. Agric. Ecosyst. Environ. 2016, 216, 374-386. [CrossRef]

16. Win, A.T.; Koki, T.; DaisUKe, I.; Seiya, C.; Takashi, M.; NatsUKo, T.; Taiichiro, O.; Tadashi, H. Effect of two whole-crop rice (Oryza sativa L.) cultivars on methane emission and $\mathrm{Cu}$ and $\mathrm{Zn}$ uptake in a paddy field fertilized with biogas slurry. Soil Sci. Plant Nutr. 2016, 62, 99-105. [CrossRef]

17. Duan, G.L.; Zhang, H.M.; Liu, Y.X.; Jia, Y.; Hu, Y.; Cheng, W.D. Long-term fertilization with pig-biogas residues results in heavy metal accumulation in paddy field and rice grains in Jiaxing of China. Soil Sci. Plant Nutr. 2012, 58, 637-646. [CrossRef]

18. Rana, M.M.; Al Mamun, M.A.; Zahan, A.; Zahan, A.; Ahmed, M.N.; Jalil Mridha, M.A. Effect of planting methods on the yield and yield attributes of short duration Aman rice. Am. J. Plant Sci. 2014, 5, 251-255. [CrossRef]

19. Watanabe, K.; Koji, S.; Hidaka, K.; Nakamura, K. Abundance, diversity, and seasonal population dynamics of aquatic Coleoptera and Heteroptera in rice fields: Effects of direct seeding management. Environ. Entomol. 2013, 42, 841-850. [CrossRef] [PubMed]

20. Thakur, A.K.; Roychowdhury, S.; Kundu, D.K.; Singh, R. Evaluation of planting methods in irrigated rice. Arch. Agron. Soil Sci. 2004, 50, 631-640. [CrossRef]

21. Ko, J.Y.; Kang, H.W. The effects of cultural practices on methane emission from rice fields. Nutr. Cycl. Agroecosyst. 2000, 58, 311-314. [CrossRef]

22. Qiang, G. Research progress on cultivation technique of direct-seeding rice in the middle and lower reaches of the Yangtze River. South China Agric. 2015, 18, 36-37. (In Chinese)

23. Balasubramanian, V.; Hill, J.E. Direct seeding of rice in Asia: Emerging issues and strategic research needs for the 21st century. In Direct Seeding: Research Strategies and Opportunities; Pandey, S., Mortimer, M., Wade, L.P., Lopez, K., Hardy, B., Eds.; International Rice Research Institute: Metro Manila, Philippines, 2002; pp. 15-39.

24. Bhushan, L.; Ladha, J.K.; Gupta, R.K.; Singh, S.; Tirol-Padre, S.; Saharawat, Y.S.; Gathala, M.; Pathak, H. Saving of water and labor in a rice-wheat system with no-tillage and direct seeding technologies. Agron. J. 2007, 99, 1288-1296. [CrossRef]

25. Farooq, M.; Basra, S.M.A.; Asad, S.A. ComParison of conventional puddling and dry tillage in rice-wheat system. Paddy Water Environ. 2008, 6, 397-404. [CrossRef]

26. Mahmood, N.; Chatha, Z.A.; Akhtar, B.; Muhammad, S. Response of rice to different sowing methods. Asian J. Plant Sci. 2002, 1, 144-145.

27. Huang, L.F.; Gao, W.; Zhu, Z.J.; Liu, X.C.; Quan, X.Y.; Xu, X.; Wang, Y.L.; Tao, X.T.; Zhuang, H.Y. The effects of different combinations of large-scale pig farm waste water and nitrogen fertilizer on wheat dry matter accumulation and yield formation. China Agric. Sci. Bull. 2012, 28, 165-170. (In Chinese)

28. Gao, W.; Lu, D.M.; Miao, C.Y.; Wang, Y.L.; Quan, X.Y.; Zhuang, H.Y.; Lu, J.F. Effects of pig slurry form large-scale pig farm on rice yield formation and quality. J. Agro-Environ. Sci. 2012, 31, 2256-2264. (In Chinese) 
29. Gao, W.; Wang, Y.L.; Tao, X.T.; Shi, J.Q.; Xu, X.; Lu, J.F.; Zhuang, H.Y. Effects of pig slurry from large-scale pig farm on medium, micro-and heavy elements contents of rice. J. Agro-Environ. Sci. 2013, 32, 1639-1647. (In Chinese)

30. Wu, Q.; Leung, J.Y.S.; Geng, X.; Chen, S.; Huang, X.; Li, H.; Huang, Z.; Zhu, L.; Chen, J.; Lu, Y. Heavy metal contamination of soil and water in the vicinity of an abandoned e-waste recycling site: Implications for dissemination of heavy metals. Sci. Total Environ. 2015, 506, 217-225. [CrossRef] [PubMed]

31. Zhu, H.; Zhong, H.; Wu, J. Incorporating rice residues into paddy soils affects methylmercury accumulation in rice. Chemosphere 2016, 152, 259-264. [CrossRef] [PubMed]

32. Supervising Department of Quality and Technology of China. Available online: http://news.foodqs.cn/ jcbz03/200391022013.htm (accessed on 10 September 2003). (In Chinese).

33. Mantovi, P.; Baldoni, G.; Toderi, G. Reuse of liquid, dewatered, and composted sewage sludge on agricultural land: Effects of long-term application on soil and crop. Water Res. 2005, 39, 289-296. [CrossRef] [PubMed]

34. Liu, W.K.; Du, L.F.; Yang, Q.C. Biogas slurry added amino acids decreased nitrate concentrations of lettuce in sand culture. Acta Agric. Scand. B Soil Plant Sci. 2009, 59, 260-264.

35. Galavi, M.; Yosefi, K.; Ramrodi, M. Effect of bio-phosphate and chemical phosphorus fertilizer accompanied with foliar application of micronutrients on yield, quality and phosphorus and zinc concentration of maize. J. Agric. Sci. 2011, 3, 22-29. [CrossRef]

36. Zaniewicz-Bajkowska, A.; Rosa, R.; Franczuk, J.; Kostern, E. Direct and secondary effect of liming and organic fertilization on cadmium content in soil and in vegetables. Plant Soil Environ. 2007, 53, 473-481.

37. Bian, B.; Wu, H.S.; Lv, L.; Fan, Y.M.; Lu, H.M. Health risk assessment of metals in food crops and related soils amended with biogas slurry in Taihu Basin: Perspective from field experiment. Environ. Sci. Pollut. Res. 2015, 22, 14358-14366. [CrossRef] [PubMed]

38. Wu, J.; Yang, Q.; Yang, G.; Shen, F.; Zhang, X.H.; Zhang, Y.Z. Effects of biogas slurry on yield and quality of oil-seed rape. J. Plant Nutr. 2013, 36, 2084-2098. [CrossRef]

39. Liu, W.K.; Yang, Q.C.; Du, L.F. Soilless cultivation for high-quality vegetables with biogas manure in China: Feasibility and benefit analysis. Renew. Agric. Food Syst. 2009, 24, 300-307. [CrossRef]

40. Zhang, Z.J.; Xie, C.L.; Xie, R.K.; Lang, Y.Z.; Yang, L.; Zhang, J.F.; Zhu, Q.S. Population production capacity of direct-seeding rice in central Jiangsu Region and effects of nitrogen application. Acta Agron. Sin. 2011, 37, 677-685. (In Chinese) [CrossRef] 